İş ve İnsan Dergisi I The Journal of Human and Work

Y1l | Year: Nisan | April 2017

Cilt-Sayı | Volume-Issue: 4 (1)

ss I pp: $17-33$

doi: 10.18394/iid.303183

e-ISSN 2148-967X

http://dergipark.gov.tr/iid/

Araştırma Makalesi

\title{
Psikolojik Sermayenin İşe Yabancılaşmaya Etkisinde Örgütsel Desteğin Aracılık Rolü
}

\author{
Mediating Role of Organizational Support on the Effect of Psychological Capital on \\ Work Alienation
}

\author{
Abdullah Çalışkan ${ }^{a}$, Nazmiye Ülkü Pekkan*, b
}

\section{MAKALE BILGISİ}

Anahtar Kelimeler:

Psikolojik sermaye, işse yabancilaşma, Örgütsel destek, Aracllik etkisi

\section{Tarihler :}

Geliş 09 Ekim 2016

Düzeltme geliş 02 Mart 2017

Kabul 02 Mart 2017

\begin{abstract}
ÖZ
Bu çalışmada, psikolojik sermayenin ve örgütsel desteğin işe yabancllaşma üzerine etkileri araştırılmıştır. Ayrıca psikolojik sermaye ile işe yabancılaşma arasında örgütsel desteğin aracılık rolüne bakılmıştır. Bu amaçla, Ankara ilinde savunma sanayi sektöründe görev yapan 396 çalışandan anket yolu ile elde edilen verilerden yararlanılmıştır. Çalışmada değişkenler arası ilişkiler ve etkileri korelasyon ve regresyon analizleri ile ortaya konulmuştur. Araştırma sonucunda psikolojik sermayenin ve örgütsel desteğin işe yabancılaşma üzerine etkilerinin bulunduğu, psikolojik sermayenin alt boyutlarının, çalışanların örgütsel destek algılarını pozitif ve anlaml olarak, işe yabancılaşmay ise negatif ve anlaml olarak etkilediği tespit edilmiştir. Ayrıca, algılanan örgütsel desteğin, psikolojik sermaye alt boyutları ve işe yabancllaşma düzeyleri üzerine etkisinde kısmi aracılık rolü olduğu belirlenmiştir.
\end{abstract}

\section{ARTICLE INFO}

\section{Keywords:}

Psychological capital, Work alienation, Organizational support, Mediating effect.

\section{Article history:}

Received 09 October 2016

Received in revised form 02

March 2017

Accepted 02 March 2017

\begin{abstract}
A B S T R A C T
In this study, the effects of psychological capital and organizational support on work alienation has been researched. Also mediation role of organizational support has been examined between work alienation and psychological capital. For this purpose, the data that obtained via survey from a participant employee at defence industry sector at Ankara city has been used. The relations and effects between variables are presented by correlation and regression analyses. With this study, it has been identified that psychological capital and organizational support have effects on work alienation, and the sub-dimensions of psychological capital is affecting all variable factors that used positively and significantly; but affecting work alienation negatively. Perceived organizational support has a partial mediating role on psychological capital and employees `work alienation level has been identified.
\end{abstract}

\footnotetext{
a Toros Üniversitesi, Sağlık Bilimleri Yüksekokulu, Sağlık Yönetimi Bölümü, Mersin, Türkiye.

*, b İletişim Kurulacak Yazar. Osmaniye Korkut Ata Üniversitesi, Sosyal Bilimler Enstitüsü, İşletme Anabilim Dalı, Osmaniye, Türkiye. nazmiyeulku.pekkan@gmail.com
} 


\section{GİRIŞ}

Globalleşmeyle birlikte rekabet şartlarının oldukça zorlu olduğu günümüz iş yaşamında faaliyet gösteren örgütlerin, varlıklarını sürdürebilmek için çok çeşitli çabalarla etkinliklerini arttırmaları gerekmektedir. İş örgütlerinin etkili olması öncelikle verimli çalışmalarına bağlıdır. Sağlıklı ve verimli çalışan bir örgütte amaçlar bireylerin istek ve beklentilerine de uygun olarak işler. Bu gibi örgütlerin çabalarının temelinde örgütü ayakta tutan en önemli unsurlardan biri olan "insan kaynağı” yer almaktadır. İnsan kaynağının önemi arttıkça insan sermayesi ve psikolojik sermaye gibi kavramlar da öne çıkmaya başlamış ve bu sayede bu değişkenler teori ve uygulamalarda araştırma konusu olarak karşımıza çıkmıştır (Luthans, Avey, Avolio \& Peterson, 2010; Topçu \& Ocak, 2012). Örgütlerin faaliyetlerini sürdürüp etkili ve verimli bir şekilde gelişmelerinde örgüt içerisinde bulunan çalışanların katkıları oldukça önemli bir yer tutmaktadır. Bu bağlamda, çalışanların örgüt içerisinde faaliyette bulunurken sergiledikleri tutum ve davranışların örgütsel başarıya ulaşmada etkili olduğu düşünülmektedir. Bu nedenle, örgütsel başarıya ulaşmak amacıyla çalışan performansını etkileyebilecek faktörlerin belirlenmesi, sonrasında bu faktörlerin olumsuz etkilerinin ortadan kaldırılması ya da minimize edilmesi bireysel ve örgütsel hedeflere ulaşmada faydalı olabilecektir. Çalışanların fikirlerinin önemsenmesi ve kendisine işle ilgili veya iş dışı her konuda destek olunması onların performanslarını artıracaktır. Fikirlerine değer verilmediğini hisseden, yaptığ 1 işin değersiz olduğunu düşünen, kendini bağlı bulunduğu örgüte ait hissetmeyen çalışanlar bir süre sonra işe yabancılaşmaya başlamaktadır. Bu durum ise örgütler açısından en sıkıntılı durumlardan birisini oluşturmaktadır. Yabancılaşma sorunu yaşayan çalışanların zaman içerisinde iş yerine aidiyet duygusunu tamamen kaybederek iş yerinden ayrılmak için farklı arayışlara yönelmesi örgüt ve çalışan açısından beklenen olumsuz sonuçlardan biri olarak karşımıza çıkmaktadır (Özdoğan, 2014: 60).

Bu çalışmanın ilk amacı, yoğun rekabet ortamında önemi her geçen gün artan çalışanların psikolojik sermayelerinin işe yabancılaşmalarını etkileyen bir değişken olup olmadığını belirlemek, ikinci amacı ise, çalışanların sahip oldukları psikolojik sermaye düzeyleri ile işe yabancılaşma ilişkisinde örgütsel desteğin aracılık etkisinin bulunup bulunmadığını incelemektir. Bunun için araştırmanın kuramsal bağlamına uygun bir örneklemden elde edilen veriler 1şığında çalışma yürütülmüştür. Ulusal yazında psikolojik sermaye - işe yabancılaşma ilişkisini ele alan sınırlı sayıda çalışmaya ulaşılabilmiş olması (Tokmak, 2014; Beğenirbaş, 2015) ve bu çalışmada üçüncü bir değişken olan örgütsel desteğin aracılık rolünün araştırılması ile elde edilecek sonuçlar bu çalışmanın önemini artırmaktadır. Çalışmanın yazına yapacağı katkı dışında çalışanlarından daha etkin faydalanmak isteyen işletmeler için de önemli katkılarının olabileceği düşünülmektedir.

\section{KAVRAMSAL ÇERÇEVE}

\subsection{Psikolojik Sermaye}

Psikolojik sermaye kavramı, küreselleşen dünyada gittikçe farklılaşan bir ekonomik çevrede faaliyet göstermek durumunda olan günümüz iş örgütlerinin rekabet içerisinde olduğu rakiplerinden farklılaşarak avantaj sağlaması ve bu avantajın sürdürülmesinde üretim faktörlerinden biri olan "insan"1n en önemli bileşen olarak görülmesi doğrultusunda karşımıza çıkan bir kavramdır.

İş örgütlerinde, çalışanların davranışlarını ve bu davranışların nedenlerini kişisel özelliklerden yola çıkarak inceleyen psikoloji bilimi, ürettiği birtakım bilimsel tekniklerle insan kaynağının işletme yönetimine büyük ölçüde yardımcı olmasını sağlamaktadır (Eren, 2014: 3). Psikolojideki pozitif yaklaşım, insan kaynağı yönetimini de etkilemiş, pozitif örgütsel davranış ve pozitif psikolojik sermaye kavramlarının ortaya çıkmasına vesile olmuştur (Akçay, 2011: 77). Psikolojik sermaye, pozitif psikolojinin bir çıktısı olarak olayları ve durumları pozitif yönde algılayan bireylerin daha fazla gelişeceği düşüncesiyle teorik altyapısını bulmuştur (Harms \& Luthans, 2012: 590). Bu sayede kavram hakkında birçok tanım yapılmıştır. Pozitif örgütsel davranış kapsamında ortaya çıkan psikolojik sermaye, psikologlar tarafindan bireysel verimliliği geliştiren kişisel bir özellik olarak tanımlanmaktadır (Gohel, 2012: 35). Bu yeni yaklaşım, çalışan performansının artırılması ve dolayısıyla örgütsel başarının elde edilmesinde, ölçülebilen, geliştirilebilen ve yönetilebilen insan kaynaklarının pozitif biçimde yönlendirilmiş güçlü yönlerini ve psikolojik kapasitelerini araştırmaktadır (Turner, Barling \& Zaharatos, 2002: 715). Diğer bir ifadeyle örgütte çalışanların gösterdiği davranışlarla örgüt çıktıları arasında bağlantı kurmaktadır (Abbas \& Raja, 2010: 8). Psikolojik sermaye kavramı, iş performansı (Luthans, Norman, Avolio \& Avey, 2008: 233), iş tatmini (Luthans, Avolio, Avey \& Norman, 2007: 560), iş stres düzeyi (Avey, Luthans \& Jensen, 2009: 682), iş devamlılığ 1 , örgütsel bağlılık, sinizm (Avey vd., 2008: 62) gibi örgütsel unsurlarla da ilişkilidir. Kisaca tanımlamak gerekirse; psikolojik sermaye, "bireyin pozitif psikolojik gelişme hali" olarak tanımlanmakta ve psikolojik sermaye bireyde "Ben kimim?" "Kim olacağım?" sorularının cevabını aramaktadır (Luthans, Youssef \& Avolio, 2006: 2). 
Psikolojik sermaye, örgütlerde önemi gittikçe artan insan kaynakları uygulamalarının anlaşılması ve yönetilmesi konusunda yeni ve farklı bir bakış açısı getirmektedir. Bu bakış açısını diğer yaklaşımlardan ayırt edebilmek için psikolojik sermaye kavramının belli başlı özelliklerini bilmekte yarar vardır. $\mathrm{Bu}$ özellikler şu şekilde sıralanabilmektedir (Nelson \& Cooper, 2007: 11 akt. Polatç1, 2014: 116):

- Psikolojik sermaye, beşeri sermayeden daha fazlasını ifade etmektedir.

- Psikolojik sermaye, sosyal sermayeden daha fazlasını ifade etmektedir.

- Psikolojik sermaye pozitiftir.

- Psikolojik sermaye eşsizdir.

- Psikolojik sermaye teori ve araştırma tabanlıdır.

- Psikolojik sermaye ölçülebilirdir.

- Psikolojik sermaye durum temellidir, bu nedenle geliştirilebilirdir.

- Psikolojik sermaye iş performansı üzerinde etkilidir.

Psikolojik sermaye, araştırma, tartışma ve gelişmeye açık bir kavramdır. $\mathrm{Bu}$ sebeple bilişsel boyut içerisinde yer alan yaratıcılık ve bilgelik; duygusal boyutta yer alan mizah, iyi oluş; sosyal boyutta yer alan duygusal zekâ, bağışlayıcılık, minnettarlık ve üst düzey boyutta yer alan spiritüalizm, cesaret, otantiklik gibi çok çeşitli kavramların gelecek çalışmalarda araştırılması psikolojik sermaye kavramını daha da geliştirecektir. $\mathrm{Bu}$ çalışmada psikolojik sermayenin Luthans, Youssef ve Avolio (2007) tarafindan geliştirilmiş ve literatürde kabul görmüş dört temel boyutu ele alınmıştır. Bu boyutlar; zor görevleri başarıyla tamamlamak için yeterli çabayı gösterme ve sorumluluk almak için güvene sahip olmayı ifade eden öz yeterlilik, şimdi ya da gelecekte başarılı olma konusunda pozitif bir atıf geliştirmeyi ifade eden iyimserlik, hedeflere yönelik azim göstermek ve gerektiğinde başarılı olmak için hedeflere giden yeni yollar bulmayı ifade eden umut ve son olarak sorunlar ve zorluklar tarafindan kuşatıldığında başarıya ulaşmak için kendini toparlamak ve bu içine düşülen durumu kaldırmayı ifade eden dayanıklılık olarak ifade edilmektedir (Luthans vd., 2007 :3).

Öz yeterlilik: Öz yeterlilik, kökeni bireylerin kendi yeterlilikleri hakkındaki kanaatlerine ve bunun davranışlara etkisi hakkında çalışmalar yapan Bandura'nın "sosyal-biliş teorisi”"nde ortaya konan bir kavramdır (Bandura, 2001: 5; Bıkmaz, 2004: 178;
Akçay, 2011: 81). Bandura, bireyin bir davranış1 gerçekleştirmesi için gereken motive edici unsurları beklenen sonuç ve bu sonuca verilen değer olarak ifade etmiştir. Bu unsurlara daha sonra öz yeterliliği eklemiştir. Öz yeterliliğin motivasyonu hem olumlu hem de olumsuz yönlerden etkilediğini söylemek mümkündür. Kendine güveni (öz yeterliliği) yüksek olan insanlar hedeflerine ulaşmak için zorluklara karşı motivasyonlarını ve performanslarını yükseltecek zorlayıcı görevler seçerler (Çavuş \& Gökçen, 2015: 245).

Iyimserlik: Psikolojik sermayenin diğer bir boyutu olan iyimserliği, hedefe ulaşmak için gösterilecek gayret uğruna kişinin karşılaşabileceği olayların sonuçları hakkında ısrarcı davranmasını sağlayacak şekilde, kişinin hayatta başına iyi şeylerin geleceğine dair genellenmiş bir beklenti olarak tanımlamak mümkündür (Luthans vd., 2007: 87). İyimserliğin beklentiye dayanması sebebiyle gerçek dışı bir değerlendirme olduğu ve henüz kontrolü sağlanmamış bir sürece dayandığını söylemek mümkündür. Özel bir durumda bireyin ne başardığının objektif bir değerlendirmesini ve o süreçte verilmiş uygun kaynakların da değerlendirilmesini içerir (Peterson \& Luthans, 2003: 28).

Umut: Psikolojik sermayenin ölçülebilir boyutlarından birisi olarak umut, günlük yaşantımızın hemen hemen her alanında sıkça kullanılan bir kavram olarak öne çıksa da, pozitif psikoloji alanında üzerinde çokça araştırmalar yapılmış, köklü bir teorik alt yapıya sahiptir (Jensen \& Luthans, 2006: 261). Umut, amaca yönelik enerji ve birbirinin yerine geçebilecek türde yolların karşılıklı etkileşiminden ortaya çıkan pozitif motivasyonel bir durumdur (Brandt, Gomes \& Boyanova, 2011: 270). Umut, değerli amaçlar belirleme inancıdır (Synder, 2000 akt. Çetin \& Basım, 2011: 82). Umut düzeyi yüksek olan bireyler ile düşük umut düzeyine sahip olan bireyler arasında, amaçlara ulaşma bakımından önemli farklılıklar olduğu bilinmektedir (Akman \& Korkut, 2003: 194). Bu sebeple, bu durum örgütler açısından incelendiğinde, örgüt içerisinde yer alan çalışanların umut düzeyi yükseldikçe örgütün değerinin de artacağı beklenmektedir (Yıldırım, 2014: 80).

Dayanıklılı: Psikolojik sermayenin boyutlarından biri olan dayanıklılık kavram olarak, sıkıntı, belirsizlik, çatışma, başarısızlık gibi olumsuz durumlar ile pozitif değişim, ilerleme ve artan sorumluluk gibi olumlu durumlar karşısında adım atma, harekete geçme olarak tanımlanmaktadır. (Avey vd., 2008: 4). Diğer bir tanıma göre ise dayanıklılık, risk veya zorluklarla karşı karşıya kalındığında, bu durumlara pozitif tepki gösterme ve uyum sağlamak olarak belirtilmektedir (Norman, Avey, Nimnicht \& Pigeon, 2010: 381). 
Psikolojik sermaye, birçok pozitif örgütsel davranış kriterini bir araya getirerek bütünleştiren son derece önemli temel bir yapıdır. Bu nedenle psikolojik sermayenin tüm boyutlarının birbirleri ile ilişkili olduğu ifade edilmektedir. Örneğin umut düzeyi yüksek insanlar, zorlukların üstesinden gelme konusunda daha fazla motive olmaları sebebiyle olaylara ve durumlara karşı daha çok direnç göstermektedirler. Öz yeterlikleri yüksek insanlar, umutlarını, iyimserliklerini ve dayanıklılıklarını hayatlarına kolaylıkla uygularlar (Luthans vd, 2006: 19).

\section{2. İşe Yabancılaşma}

Yabancılaşma kavramı, Şimşek ve arkadaşları tarafından bir insanın hayatını, insanın özüne aykırı bir hayat tarzına veya insan doğasına uygun düşmeyen bir yaşam şekline büründürmesi olarak tanımlanmaktadır. Yabancılaşma esasen, insanın kendi yaşamının başrolündeki özne olmaktan çıkıp, yaşamının nesnesi durumuna gelmesi olarak da ifade edilebilir. Yabancılaşma insanın kendini, özünü gerçekleştirmeye çalışan yaratıcı insan (özne) ile yaşamın karmaşası içinde kendisini kaybeden, yani başkaları tarafından etkilenip kendisinin olmak istediğinin dışında bir yönde yönlendirilen insan (nesne) olarak ikiye ayrılmasıdır (Şimşek, Çelik, Akgemci \& Fettahlıoğlu, 2006: 570). En genel anlamda yabancılaşmayı, bireyin gerek topluma gerekse kendisine karşı anlamsız bir hissiyat içerisinde bulunması olarak ifade etmek mümkündür (Gürsoy, 2014: 5).

Yabancılaşma kavramı özellikle iş yaşamında sıklıkla karşılaşılan bir durumdur. Bugüne dek yapılan çeşitli çalışmalar incelendiğinde, yabancılaşma kavramının, bireyin içinde yaşadığı toplumun koşullarından, sosyal çevresi ve iş çevresinin koşullarından kendi bireysel koşullarına kadar birçok farklı faktörden etkilendiğini söylemek mümkündür. Yabancılaşma olgusu, siyasal ve ekonomik temelli ilişkilerde olduğu gibi bütün ilişkilerde bir bozulmayı ifade etmektedir (Tuna \& Yeşiltaş, 2014: 108). Bu bozulma neticesinde, kişiler kendi özüne ve benliğine uygun olmayan biçimde yaşamak zorunda kalarak yaşamın özünden uzaklaşabilirler. Özellikle teknolojinin insanın denetiminden çıkıp insanı denetleme aşamasına gelmesi, iş görenin iş arkadaşlarından uzaklaştırılıp teknolojiyle baş başa kalması, ürettiği ürünü kendi üretimi olarak algılayamaması ve kendi yaşamı, geleceği üzerinde denetim sahibi olamaması insanın yabancılaşmasının nedenleri olarak siralanmaktadır (Erdem, 2014: 521). Her disiplin yabancılaşmayı kendi açısından ele alarak tanımlayabilmektedir. Sosyoloji alanına göre yabancılaşma farklı, hukuk alanına göre farklı, psikolojiye göre daha farklı bir biçimde tanımlanabilmektedir. Bu çalışmada yabancılaşma, örgüt açısından işe yabancılaşma konusu olarak ele alınacaktır. Bu kapsamda incelendiğinde çalışanın işe yabancılaşması, iş görenin örgütsel süreçlerdeki kontrolünü kaybetmesi, kendisini ifade edememesi ve işine karşı güçsüzlük hissi duyması sonucunda oluşmaktadır. Bununla birlikte, bireyin işinde otonomiye ve işinin üzerinde kontrol yetkisine sahip olmaması, işe yabancılaşma duygusunun oluşmasına katkı sağlamaktadır (Ceylan \& Sulu, 2010: 67). Örgüt içerisinde çalışanın işe yabancılaşması istenmeyen bir durumdur. İşe yabancılaşma çalışanın emeğine yabancılaşmasıyla birlikte başlamaktadır. Emeğe yabancılaşma kavramında, örgüt çalışanının emeğini sanki kendi emeği değilmiş gibi görmesi söz konusudur. $\mathrm{Bu}$ kavramı ilk kez Karl Marx kullanmıştır (Başaran, 2008 akt. Erdem, 2014: 521). İşe yabancılaşmanın örgüt içerisinden kaynaklanan nedenler ve örgüt dış1 nedenler olmak üzere çok çeşitli nedenleri bulunmaktadır. Ancak genel itibariyle belirtmek gerekirse; herhangi bir şeye içten ve derinden bağlanamama, kişinin yaptığı iş ile kendini ifade edememesi, işin kendi gerçekliğiyle uyuşmaması, çalışanın işinden duygusal anlamda daha fazla soğuması, işe karşı ilgisizlik, iş ile bütünleşememe, işten geri çekilme, ilişkilerin kopukluğu ile işten ve dolayısıyla örgütten izole olma gibi duygular işe yabancılaşmanın belirtileri olarak görülmektedir (Erjem, 2005: 3; Ünsar \& Karahan, 2011: 362; Kaya \& Serçeoğlu, 2013: 314). İșe yabancılaşma, kişisel bir özellik olmasından ziyade daha çok çalışma koşullarına bağlı olarak ortaya çıkan; bireyin fiziksel ve zihinsel olarak sosyal etkileşim düzeyinden uzaklaşarak ilgisizlik ve bütünleşememe durumunu ifade etmektedir. $\mathrm{Bu}$ sebeple, örgüt içerisinde sunulan çalışma şartlarının ve neticede oluşan çalışma ortamının bireylerin işe yabancılaşma düzeylerini önemli ölçüde etkilediği düşünülmektedir (Banai, Reise \& Probst, 2004: 377; DiPietro \& Pizam, 2008: 23). Bu doğrultudan hareketle, örgüt kültürü, örgüt iklimi ve örgütsel destek gibi örgütsel faktörlerin çalışanların tutum ve davranışlarını olumlu veya olumsuz yönde şekillendirerek, bireylerin işe yabancılaşma düzeylerini arttırması ya da azaltması beklenmektedir (Kanten \& Ülker, 2014: 625).

\section{3. Örgütsel Destek}

Destek, farklı kaynaklardan gelen faydalı katkıların, takdirin, duyguların, bilgilerin bireylerde algılanan akışı olarak belirtilmektedir (Parasuraman, Greenhaus \& Granrose, 1992: 340). Her insan hayatının her evresinde başkaları tarafından desteklendiğini düşünerek kendisini iyi hisseder. Buna bağlı olarak kişinin hayatının büyük bir bölümünü çalışarak geçirdiği düşünülürse, bir örgüt içinde çalışan olarak, çalıştığ 1 yerde desteklendiğini hissetmesi son derece önemlidir. Kişinin çalıştığı kurumdan destek algılaması anlamına gelen örgütsel destek ilgili 
yazında çok karşılaşılan bir kavram olarak karşımıza çıkmaktadır (Giray \& Şahin, 2012: 2). Bireysel performanslarını arttırarak örgütsel hedeflere ulaşmak için çalışanlar örgüt içinde destek alma ihtiyacı duyarlar. Örgütsel destek, “çalışanların örgüte katkılarının değerinin bilinmesi ve çalışanların mutluluğunun önemsenmesinin derecesine bağl1 olarak geliştirdikleri algılar" olarak açıklanmaktadır (Ring, 2011: 157). Örgütsel destek en genel anlamıyla, örgüt değerlerinin çalışanların esenliğini sağlayacak biçimde ve onların mutluluklarını artırmaya yönelik nitelik taşımasının algılanması durumudur (Eisenberger, Huntington, Hutchison \& Sowa, 1986: 501). Örgütsel destek, belirli bir olayda bir anda ortaya çıkan bir durum değildir. Aksine, çalışanların örgütte bulundukları süre boyunca örgüt tarafından gördükleri olumlu muamelenin geçmişi ile ilgilidir. Örgütsel destek, iyileştirilmiş iş metotlarını ve çalışma koşullarını, çalışanların refahına duyulan ilgiyi, ulaşılabilir hedefleri, iş görenlerine anlayış gösteren örgütü, yeterli bilgiyi, iletişimi, cesaretlendirmeyi ve uyuşmazlıklara toleransı içine alabilir (Karakurt, 2012: 30).

Örgütsel destek teorisine göre çalışanlar, sosyoduygusal ihtiyaçlarının karşılanmasında, çabalarının ödüllendirilmesinde organizasyonun gönüllü olduğu kanaatine vardıklarında, mutluluklarının önemsendiği, çabalarının takdir edildiğine dair inançlar oluştururlar. Çalışanlarda oluşan tüm bu inançlar, örgütsel destek olarak adlandırılmaktadır (Eisenberger vd., 1986: 500). Çalışanların fikirlerinin önemsenmesi ve kendisine işle ilgili veya iş dışı her konuda destek olunması onların performanslarını artıracaktır. Çalışanların öneri ve şikâyetlerinin dinlenmemesi, dikkate alınmaması, kişilerin örgütte kabul görmediklerini hissetmelerine, iş etkileşiminden doğan psikolojik anlamın yokluğuna neden olabilir. Bu gibi durumlar çalışanlar tarafindan algılanan örgütsel destek inancının azalmasına sebep olabilecektir (Çakır, 2001: 68; Özdevecioğlu, 2003: 117).

\section{DEĞISSTENLER ARASI ILISŞKILLER VE HIPOTEZLERIN OLUŞTURULMASI}

\subsection{Psikolojik Sermaye ve İşe Yabancılaşma İlişkisi}

İşe yabancılaşmayı etkileyen unsurların incelendiği çalışmalara bakıldığında (Afrasiabi, Solokloo \& Ghodrat1, 2013; Nabavi \& Shahryari, 2014; Sayü, 2014; Özdoğan, 2014; Yalçın \& Koyuncu, 2014; Erdem, 2014; Kanten \& Ülker, 2014; Yorulmaz, Altınkurt \& Yılmaz, 2015) genel itibariyle örgütlerdeki iletişim şekli, politika ve prosedürler, algılanan yönetim ve liderlik tarzı, demokratik ve sosyal bütünleşmenin sağlanamaması, güven duygusu, 1lıman olmayan örgüt iklimi, örgüt içi koçluk uygulamaları, çalışanların işlerinde kendilerini ifade edememeleri, gerçek duygu ve düşüncelerini gizlemek durumunda kalmaları, işin gerektirdiği roller gibi çok çeşitli bireysel ve örgütsel faktörler işe yabancılaşma duygusunun oluşmasında önemli etkiye sahip değişkenler olarak belirtilmiştir. Bu bağlamda, eğitim kurumlarındaki yabancılaşma süreci ve kurumsal değerler doğrultusunda eğitim kurumlarında yapılan çalışma sonucunda; yabancılaşmanın kişilerde zihinsel, fiziksel ve duygusal bir takım gelişmeleri aksattığı belirtilmiştir (Polat \& Yavaş, 2012). Birbirinden farklı hizmet sektöründe çalışanların işe yabancılaşma durumları üzerinde gerçekleştirilen bir çalışmada, çalışanların faaliyette bulundukları işlerde işin gerektirdiği rol ve kendi duyguları arasında kalarak kendilerini ifade edemedikleri ve bu sebeple işe yabancılaştıkları sonucuna ulaşmışlardır (Kaya \& Serçeoğlu, 2013). Psikolojik sermaye, umut, iyimserlik, öz-yeterlilik ve dayanıklılık boyutları ile açıklanan ve bireylerin pozitif güçlerine odaklanan bir kavram olarak karşımıza çıkmaktadır. Değişen ve gelişen dünya düzeninde hayatın büyük bir bölümünün bir organizasyona bağlı olarak iş başında çalışılarak geçirildiği göz önüne alındığında insanların işlerinden olan beklentilerinin artması makul karşılanacaktır. Bireyler, umut, iyimserlik, öz-yeterlilik ve dayanıklılık gibi psikolojik sermaye unsurları ile bağlı bulundukları örgüt içerisinde güven duygusu geliştirerek daha etkin çalışmalar ile örgütsel çıktılara katkıda bulunma isteği içerisinde olacaklardır. Ancak bireylerin bu istek, çalışma azmi ve motivasyonlarının devamlılı̆̆ının sağlanmasında örgüt desteğinin son derece önemli bir etkisi bulunmaktadır. Örgüt tarafından yönetim desteği göremeyen, kendisine sorumluluk ve yetki verilmeyen, kendi yetenek ve becerilerini işe aktaramayacak rutin bir çalışma ortamı içerisinde sıkışan, güçlü yönlerini ve psikolojik kapasitesini genişletemeyen iş gören işinin devamlılığı ve örgütünün istikrarı ve güçlenmesini sağlayacak tutum ve davranışlardan kaçınarak işe yabancılaşacaktır. Psikolojik sermaye ve işe yabancılaşma kavramsal olarak değerlendirildiğinde aralarında anlamlı ve güçlü bir negatif ilişki olması gerektiği düşünülmektedir. Diğer bir ifadeyle, psikolojik sermaye düzeyi yüksek olan çalışanların düşük olanlara göre işe yabancılaşmalarının daha az olacağı değerlendirilmekle birlikte yapılan alan yazın araştırmasında psikolojik sermaye ve işe yabancılaşma değişkenlerini bir arada inceleyen sınırlı sayıda çalışma olduğu görülmektedir (Tokmak, 2014; Beğenirbaş, 2015). Bu çalışmalardan biri Tokmak tarafından 2014 yılında müşteri memnuniyetinin lojistik sektöründe yer alan bir işletmenin çalışanlarının katılımı ile duygusal emek ile işe yabancılaşma ilişkisinde psikolojik sermayenin 
düzenleyici etkisinin bulunup bulunmadığını araştırmak amacıyla gerçekleştirilmiştir. Çalışma sonucunda, çalışanların duygusal emek yoğunluğundaki artışın, işe yabancılaşmalarını artırdığı ve onların sahip olduğu psikolojik sermayelerinin duygusal emek ile işe yabancılaşma arasındaki ilişkide düzenleyici bir rol üstlendiği sonucuna ulaşılmıştır. Psikolojik sermaye ve işe yabancılaşma arasındaki ilişkinin incelenmesine yönelik yapılmış çalışmaların azlığı, işe yabancılaşmanın önemli öncüllerini inceleme ihtiyacını doğurmaktadır. $\mathrm{Bu}$ öncüllerin en önemlilerinden biri olarak yazında sıkça çalışılmış olan tükenmişlik kavramı ve işten ayrılma niyeti ile psikolojik sermaye arasında yapılan çalışmalar incelendiğinde, psikolojik sermayenin tükenmişliği ve işten ayrılma niyetini negatif yönde anlamlı olarak etkilediği sonucuna ulaşılmıştır (Topçu \& Ocak, 2012, Çetin, Şeşen \& Basım, 2013; Hansen, Buitendach \& Kanengoni, 2015; Bester, Stander \& Zyl, 2015). Psikolojik sermayenin dört boyutu (umut, iyimserlik, öz-yeterlilik, dayanıklılık) ile ilgili değişkenlerin arasındaki ilişkiyi inceleyen araştırmalara ise rastlanmamıştır. $\mathrm{Bu}$ bakımdan psikolojik sermayenin dört boyutunun ayrı ayrı ele alınarak çalışma konusu değişkenlerle ilişkilerinin araştırılıyor olması, bu çalışmayı özgün kılan bir özellik olmaktadır. Kuramdan ve görgül araştırmalardan yola çıkılarak oluşturulan hipotezler aşağıda sunulmuştur:

Hipotez 1: Çalışanların algıladıkları öz-yeterlilik düzeyi işe yabancılaşmayı negatif ve anlamlı olarak etkiler.

Hipotez 2: Çalışanların algıladıkları iyimserlik düzeyi işe yabancılaşmayı negatif ve anlamlı olarak etkiler.

Hipotez 3: Çalışanların algıladıkları umut düzeyi işe yabancılaşmayı negatif ve anlamlı olarak etkiler.

Hipotez 4: Çalışanların algıladıkları dayanıklılık düzeyi işe yabancılaşmayı negatif ve anlamlı olarak etkiler.

\section{2. Örgütsel Destek ve İşe Yabancılaşma İilişkisi}

İşe yabancılaşma kavramı, bireyin çevresinden, yaptığı işten ya da benliğinden ayrılma veya uzaklaşma duygusudur. İş örgütlerinde işe yabancılaşma kavramının ortaya çıkardığı birçok olumsuz sonuçlar olduğu ve verimliliği düşürdüğü bilinmektedir. Konu ile ilgili yapılan yerli ve yabancı çalışmalarda işe yabancılaşmayı ortaya çıkaran pek çok öncülün olduğu ve neticede hem örgüt hem de birey açısından olumsuz olabilen sonuçları olduğu belirtilmektedir. Yaptığı işin değersiz olduğunu düşünen, kendini bağlı bulunduğu örgüte ait hissetmeyen çalışanlar bir süre sonra işe yabancılaşmaya başlamaktadır. Bu durum ise örgütler açısından en sıkıntılı durumlardan birisini oluşturmaktadır. Yabancılaşma sorunu yaşayan çalışanların zaman içerisinde iş yerine aidiyet duygusunu tamamen kaybederek iş yerinden ayrılmak için farklı arayışlara yönelmesi örgüt ve çalışan açısından beklenen olumsuz sonuçlardan biri olarak karşımıza çıkmaktadır (Özdoğan, 2014: 60). Aksi düşünülecek olursa; çalıştığı örgütte uygun bir çalışma ortamına sahip olan çalışanın, örgüt ile arasında güçlü bir duygusal bağ oluşarak iş performansının artması ve bunlar doğrultusunda yabancılaşma hissinde azalma olması beklenmektedir (Tekingündüz, Kurtuldu \& Eğilmez, 2016: 689). Yerli ve yabancı literatürde örgütsel destek ve işe yabancılaşma değişkenleri arasındaki ilişkiyi inceleyen çalışma sayısı az olmakla birlikte bu iki değişkenin öncülleri ya da yakın kavramlarla yapılmış çalışmalar mevcuttur. İşe yabancılaşmanın sonucu olarak gösterilebilecek işten ayrılma niyetinin algılanan örgütsel destek ile ilişkisini araştırmak üzere Turunç ve Çelik (2010) tarafından yapılan çalışma sonucunda, algılanan örgütsel desteğin işten ayrılma niyetini önemli ölçüde azalttığ1 bulgulanmıştır $\quad(\mathrm{r}=-, 37 \quad \mathrm{p}<0.01)$. Ring (2011) tarafından taşımacılık sektöründe çalışanlar üzerine yapılan bir diğer çalışmada algılanan örgütsel desteğin personel devir hızı üzerine etkisi araştırılmıştır. Çalışma sonucunda, işi bırakma niyeti ile algılanan örgütsel destek arasında $(r=-, 51 \mathrm{p}<0.01)$ negatif yönlü anlamlı bir ilişki bulunmuştur. Örgütsel desteğin olumsuz sonuçlarından birinin tükenmişlik olduğu (Karacaoğlu \& Arslan, 2013: 459) ve tükenmişlik kavramının da işe yabancılaşmanın önemli bir öncülü olduğu bilinmektedir. $\mathrm{Bu}$ amaçla yazın araştırmasında öne çıkan bir diğer çalışma Karacaoğlu ve Arslan (2013) tarafından çalışanların algıladıkları örgütsel desteğin tükenmişlik düzeyleri üzerine etkisini belirlemek üzere Kayseri organize sanayi bölgesinde faaliyet gösteren imalat sanayi işletmelerinde çalışan 333 kişi üzerinde gerçekleştirilmiştir. Çalışma sonucunda, çalışanlarca algılanan örgütsel destek ile genel tükenmişlik ve onun boyutlarından duygusal tükenme ve duyarsızlaşma arasında $(\beta=-, 208)$ negatif yönlü ve zayıf bir etkileşim, öte yandan düşük kişisel başarı hissi boyutu $(\beta=, 303 \mathrm{p}=0.00)$ ile pozitif yönlü ve yine zayıf bir etkileşimin olduğu sonucuna varılmıştır. Tüzün Kalemci, Çetin ve Basım (2014) tarafindan Türkiye'de faaliyet gösteren devlet üniversitelerinde görev yapan 255 akademisyen üzerinde destekleyici örgütsel uygulamaların işten ayrılma niyeti üzerindeki etkisini incelemek üzere gerçekleştirilen araştırma, algılanan örgütsel destek ve amir desteği ile işten ayrılma niyeti arasında $(\mathrm{r}=-, 53 \mathrm{p}<0.01)$ ters yönlü bir ilişki olduğunu göstermiştir. İşten ayrılma niyetinin algılanan örgütsel destek üzerindeki etkisini belirlemek üzere yapılan diğer bir çalışma, 


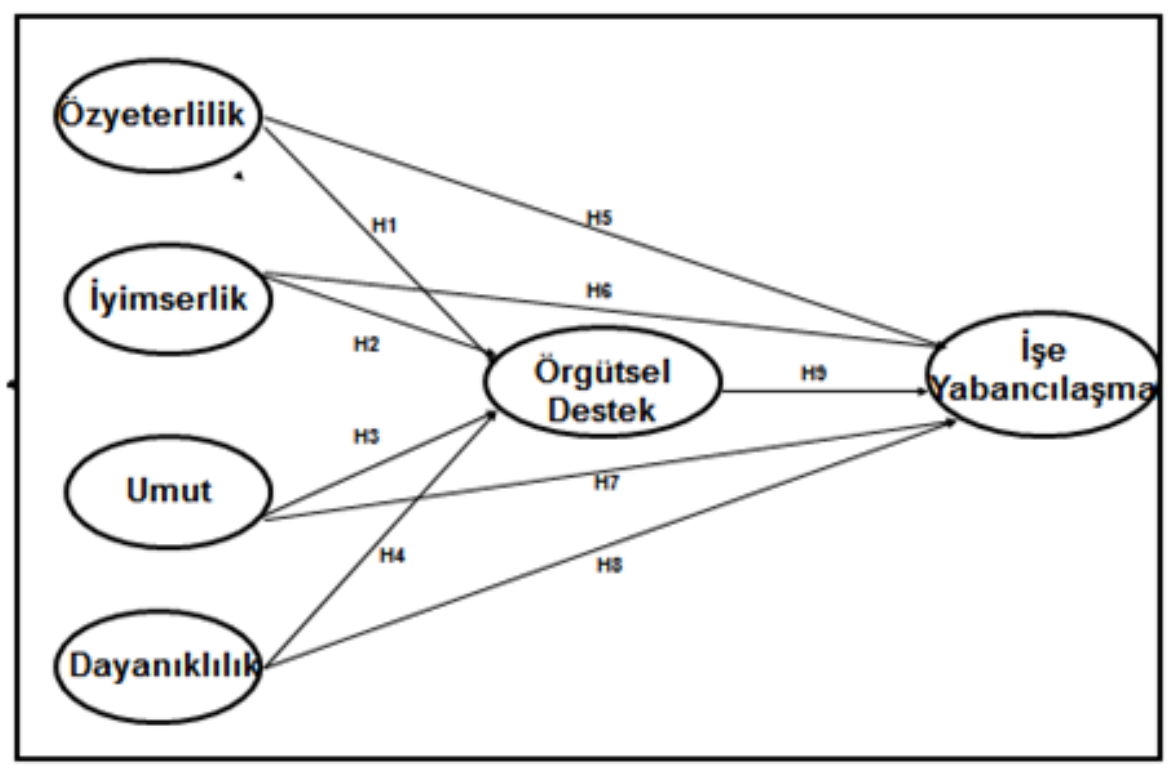

Şekil 1. Araştırm a Modeli ve Hipotezler

Türkiye'de yer alan devlet ve vakıf üniversitelerinde görev yapmakta olan 570 akademik personel üzerinde Büyükyılmaz ve Çakmak (2014) tarafından yapılan bir çalışma ile gerçekleştirilmiştir. Çalışma sonucunda, algılanan örgütsel destek ile işten ayrılma niyeti arasında negatif yönlü anlamlı bir ilişki tespit edilmiştir $(r=-, 626 \mathrm{p}<0.01)$. Hastane çalışanlarının algılanan örgütsel desteğinin, işe yabancılaşma ve örgüte bağlılığı üzerindeki etkisini ortaya koymak amaciyla İstanbul ilinde faaliyet göstermekte olan özel hastanelerden A sinıfı olarak tanımlanan 2 hastaneden 118 çalışan üzerinde gerçekleştirdikleri çalışma sonucunda, örgütsel destek algısının işe yabancılaşma üzerinde negatif yönde orta düzeyde anlamlı korelasyon gösterdiğini $(\mathrm{r}=-0,456)$ tespit etmişlerdir. (Taştan, İşçi \& Arslan, 2014). Yapılan alan yazın taraması ve görgül araştırmalar neticesinde örgütsel destek ve işe yabancılaşma arasında negatif yönlü bir ilişkinin bulunduğu düşünülmektedir. $\mathrm{Bu}$ bilgiler 1şı̆̆ında kurulan hipotez;

Hipotez 9: Çalışanların algıladıkları örgütsel destek düzeyi işe yabancılaşma düzeylerini negatif ve anlamlı olarak etkiler.

Yapılan araştırmalardan elde edilen bulgulardan, psikolojik sermayenin işe yabancılaşmaya etkisinde örgütsel desteğin aracılık rolü olabileceği düşünülmektedir. Literatürde işletmelerde psikolojik sermayenin bireylerin işe yabancılaşmasının etkisinde örgütsel desteğin aracılık rolünü inceleyen bir araştırmaya rastlanmamıştır. $\mathrm{Bu}$ ihtiyaçtan yola çıkılarak psikolojik sermayenin bireylerin işe yabancılaşmasına etkisinde örgütsel desteğin aracılık rolünü araştırmak üzere aşağıdaki hipotezler oluşturulmuştur.
Hipotez 10: Çalışanların algıladıkları öz-yeterlilik düzeyinin işe yabancılaşmayı etkisinde örgütsel desteğin aracılık etkisi vardır.

Hipotez 11: Çalışanların algıladıkları iyimserlik düzeyinin işe yabancılaşmayı etkisinde örgütsel desteğin aracılık etkisi vardır.

Hipotez 12: Çalışanların algıladıkları umut düzeyinin işe yabancılaşmayı etkisinde örgütsel desteğin aracılık etkisi vardır.

Hipotez 13: Çalışanların algıladıkları dayanıklılık düzeyinin işe yabancılaşmayı etkisinde örgütsel desteğin aracılık etkisi vardır.

Kuramdan ve görgül araştırmalardan yola çıkılarak oluşturulan araştırma modeli ve hipotezler Şekil 1'de sunulmuştur:

\section{ARASTTIRMANIN YÖNTEMİ}

Psikolojik sermayenin (PS) dört boyutunun, işe yabancılaşma (IYYB) üzerine etkisini ve bu etkide örgütsel desteğin (ÖD) aracılık rolünü belirlemeye yönelik olan bu araştırmada, öncelikle örneklem ve ölçeklere ilişkin bilgilere yer verilmiştir. Ardından örneklemden elde edilen veriler ışığında oluşturulan modele ilişkin analizler yapılmıştır. Bu kapsamda öncelikle her bir değişkenin doğrulayıcı faktör analizi yapılmış ardından değişkenler arası korelasyonlar tespit edilmiştir. Yapılan hiyerarşik regresyon analizi ile hipotezler ve aracılık etkileri test edilmiştir. Ardından aracılık etkilerini test etmek üzere Sobel testleri yapılmıştır. Tüm bu analizler sonucunda elde edilen bulgular mevcut literatür ile karşılaştırılarak yönetici ve araştırmacılara önerilerde bulunulmuştur. 
Tablo 1.Doğrulayıc1 Faktör Analizi Sonucunda Ölçeklerin Uyum İyiliö Değetleri

\begin{tabular}{|c|c|c|c|c|c|c|c|}
\hline Değişkenler & $\begin{array}{l}\text { CMIN/DF } \\
<5\end{array}$ & $\begin{array}{l}\text { GFI } \\
>.85\end{array}$ & $\begin{array}{l}\text { AGFI } \\
>80\end{array}$ & $\begin{array}{l}\text { CFI } \\
>90\end{array}$ & $\begin{array}{l}\text { NFI } \\
>90\end{array}$ & $\begin{array}{l}\text { TLI } \\
>90\end{array}$ & $\begin{array}{l}\text { RMSEA } \\
<.08\end{array}$ \\
\hline 1. Öxyeterlilik (ÖZY) & 2.8 & .98 & .98 & 99 & .98 & .99 & .04 \\
\hline 2. İyimserlik(IYYM) & 3.1 & 99 & .98 & 99 & .98 & 99 & .05 \\
\hline 3. Umut (UMT) & 3.3 & .96 & .98 & .97 & .98 & .98 & .06 \\
\hline 4. Dayamukllluk (DYN) & 1.3 & .96 & .96 & .95 & .97 & .96 & .02 \\
\hline 5. Örg. Des. (ÖD) & 3.1 & .97 & .96 & .98 & .98 & .97 & .06 \\
\hline 6.İșe Yab. (IYB) & 4.1 & .98 & .97 & .99 & .97 & .98 & .03 \\
\hline
\end{tabular}

Not: Uyum iyiliog değer aralikları "kabul edilebilir" standartlara göre düzenlenm iştir.

\subsection{Araştırmanın Örneklemi}

Araştırma evrenini Ankara'da savunma sanayi sektöründe faaliyet gösteren özel bir işletme ve bu işletme ile iş yapan taşeron savunma sanayi işletmelerinin çalışanları oluşturmaktadır. Bu evrende yaklaşık 25000 kişi çalışmaktadır. Ana kütleden \%95 güvenilirlik sınırları içerisinde $\% 5$ 'lik bir hata payı dikkate alınarak örneklem büyüklüğü 378 kişi olarak hesap edilmiştir (Sekaran, 1992). Bu kapsamda kümelere göre örnekleme yöntemiyle tesadüfî olarak seçilen işletmelerden toplam 600 kişiye anket uygulaması yapılması planlanmıştır. Gönderilen anketlerden 402'si geri dönmüş, 396's1 analiz yapmak için uygun bulunmuştur.

Araştırmaya katılanların \% 64,9'u erkek ( $\mathrm{n}=257), \%$ 76'sı (n=301) evlidir. Çalışanların \% 31,1'i $(\mathrm{n}=123)$ lise, $\% 58,3^{\prime} \ddot{u}(n=231)$ üniversite, \% 6,8'i de $(n=27)$ de lisansüstü eğitim derecesine sahiptir. Örneklemin, $\% 16,9$ 'u $(\mathrm{n}=67) \quad 18-24$ yaş, \% 31,8'i $(\mathrm{n}=126)$ 25-32 yaş, \% 29,8'i (n=118) 33-40 yaş ve \% 21,5'i de $(\mathrm{n}=85) 41$ ve yukarı yaşlar arasındadır. Çalışanların $\% 31,7$ 'si (n=125) 3 y1ldan az, \%35,8'i (n=142) 4-9 yıl arası, \% 9,5'i (n=48) 10-15 yıl aras1, \% 13,3'ü $(n=53) 16-21$ yil aras1 ve \%7'si de $(n=28)$ de 22 ve yukarı yıl iş deneyimine sahiptir.

\subsection{Araştırmanın Ölçekleri}

Psikolojik sermayenin (PS) dört boyutunun, işe yabancılaşma (IYB) üzerine etkisini ve bu etkide örgütsel desteğin (ÖD) aracılık rolünü belirlemeye yönelik olan bu araştırmada kullanılan ölçeklere ilişkin bilgiler aşağıda verilmektedir. Ölçeklerin Cronbach alfa güvenirlik katsayıları SPSS paket programı ile doğrulayıcı faktör analizleri ise Amos programı ile analiz edilmiştir.

\subsubsection{Psikolojik Sermaye (PS) Ölçeği}

Çalışanların psikolojik sermaye düzeyi ile ilgili algılarını ölçmek üzere Luthans vd. (2007) tarafından geliştirilen, Çetin ve Basım (2012) tarafindan Türkçe uyarlaması yapılan dört boyutlu (öz-yeterlilik, iyimserlik, umut ve dayanıklılık) ölçek kullanılmıştır. Ölçek, her bir boyut altışar ifade olmak üzere toplam 24 ifadeden oluşmaktadır. Bu ölçekte yer alan ifadeler, "Çalışma alanımda, hedefler/amaçlar belirlemede kendime güvenirim", "Herhangi bir problemin çözümü için birçok yol vardır", "İ̧̧imde benim için belirsizlikler olduğunda, her zaman en iyisini isterim", "Eğer zorunda kalırsam, işimde kendi başıma yeterim" şeklindedir. Ölçekte cevaplar 5'li likert ölçeği ile alınmıştır (1=Kesinlikle katılmıorum, 5=Kesinlikle katılıyorum). Çetin ve Basım (2012) tarafından yapılan güvenilirlik analizleri sonucunda, Cronbach alfa güvenirlik katsayısının öz-yeterlilik için .85, iyimserlik için .67, umut için .81 ve dayanıklılık için .68 olarak tespit edilmiştir. Ayrıca ölçeğin toplam Cronbach Alfa katsayısı 0,91 olarak hesaplanmıştır.

Ölçeğin KMO analiz sonucu sırasıyla $.88, .83, .86$ ve .87 ve Barlett testi anlamlı $(\mathrm{p}=.000)$ olarak tespit edilmiştir. Bu çalışmada ölçeğin yapı geçerliliğini test etmek maksadıyla doğrulayıcı faktör analizi yapılmıştır. Faktör analizi sonucunda verilerin ölçeğin dört boyutlu yapısına uyum sağladığı ve faktör yüklerinin öz-yeterlilik için .65 ile .78 , iyimserlik için .74-.85, umut için .76-.83ve dayanıklılık için .73-.90 arasında olduğu tespit edilmiştir. Ölçeğin uyum iyiliği değerleri diğer ölçeklerinki ile birlikte Tablo 1'de sunulmuştur. Yapılan güvenirlik analizi sonucunda ölçeğin Cronbach alfa güvenirlik katsayıları sirasıyla .90 .84 , .89 ve .81 olarak bulunmuştur.

\subsection{2. Örgütsel Destek (ÖD) Ölçeği}

Çalışanların algıladıkları örgütsel destek düzeyini belirlemek üzere Eisenberger ve arkadaşları (1986) tarafından geliştirilen, Armstrong-Stassen ve Ursel (2009) tarafindan kisaltılarak 10 maddeli hale getirilen ve Akkoç, Çalışkan ve Turunç (2012) tarafından Türkçe'ye uyarlaması yapılan ve yerli literatüre kazandırılan ölçek kullanılmıştır. Algılanan örgütsel destek ölçeğinde sorular "Çalıştığım işletmenin çıkarları için alınan sorumluluklara değer verilir" ve "Çalıştığım işletme benim iyi olmama ve 
Tablo 2. Verilere ilişkin Ortalam a, Standart Sapm a ve Korela syon Değerleri

\begin{tabular}{|c|c|c|c|c|c|c|c|c|}
\hline & Ort. & S.S. & öZY & IYM & UMT & DYN & öD & İYB \\
\hline$\overline{1.0 ̈ Z Y}$ & 3.67 & 1.23 & (90) & & & & & \\
\hline 2.İYM & 3.21 & 1.24 & $.69 * *$ & (84) & & & & \\
\hline 3.UMT & 3.89 & 1.25 & $.48 *$ & $.67^{* *}$ & (89) & & & \\
\hline 4.DYN & 3.23 & 1.22 & $.21 *$ & $.44 *$ & $.39 *$ & (81) & & \\
\hline 5. ÖD & 3.67 & 1.19 & $61 * *$ & $.78 * *$ & $.76^{* *}$ & $.53 *$ & $(87)$ & \\
\hline 6.IYYB & 2.37 & 1.20 & $-.43^{* * *}$ & $-.55 * *$ & $-.48 * *$ & $-.58 *$ & $-.74 * *$ & (82) \\
\hline
\end{tabular}

mutlu olmama önem verir" şeklindedir. Ölçekte cevaplar 5'li likert ölçeği ile alınmıştır $(1=$ Kesinlikle katılmıorum, 5=Kesinlikle katılıyorum). Akkoç vd. (2012) tarafindan yapılan güvenilirlik analizlerinde Cronbach alfa güvenirlik katsayısı .93 olarak tespit edilmiştir.

Ölçeğin KMO analiz sonucu .91 ve Barlett testi anlamlı $(\mathrm{p}=.000)$ olarak tespit edilmiștir. $\mathrm{Bu}$ analizlerin ardından AMOS paket programı ile doğrulayıcı faktör analizi yapılmıştır. Faktör analizi sonucunda verilerin ölçeğin tek faktörlü yapısına uyum sağladığı ve ölçeğin faktör yüklerinin .78 ile .87 arasında olduğu tespit edilmiştir. Ölçeğin uyum iyiliği değerleri diğer ölçeklerinki ile birlikte Tablo 1'de sunulmuştur. Yapılan güvenirlik analizi sonucunda ölçeğin toplam Cronbach alfa güvenirlik katsayıs1 .87 olarak bulunmuştur.

\subsection{3. İşe Yabancılaşma Ölçeği (îB)}

Çalışanların işe yabancılaşmasının belirlenmesinde Hirschfeld ve Hubert (2000) tarafindan geliştirilen ve Türkçe uyarlaması Özbek (2011) tarafindan yapılan ölçek kullanılmıştır. Ölçek; "İş yaşamının çoğu anlamsız aktivitelerle heba olmaktadır", "İnsanların sıkı çalışmasının bir önemi yok, sadece çok az bir kısmı gerçekten istediğini elde edebilir", "Ne kadar sıkı çalıştığının bir önemi yok, nasıl olsa istediklerini elde edemeyeceksin" şeklinde toplam 10 ifadeden oluşmaktadır. Ölçekte cevaplar 5'li likert ölçeği ile alınmıștır (1=Kesinlikle katılmıyorum, 5=Kesinlikle kat1liyorum). Özbek (2011) tarafindan yapılan güvenilirlik analizlerinde Cronbach alfa güvenirlik katsayıs1 .75 olarak tespit edilmiştir.

Çalışmada ölçeğin yapı geçerliliğini test etmek maksadıyla keşfedici faktör analizi yapılmış, verilerin ölçeğin tek faktörlü yapısına uyum sağladığı belirlenmiştir. Ölçeğin faktör yüklerinin .76 ile .84 arasında olduğu, KMO analiz sonucu .89 ve Barlett testi anlamlı $(\mathrm{p}=.000)$ olarak tespit edilmiştir. Ardından Amos paket programı ile doğrulayıcı faktör analizi yapılmış, verilerin ölçeğin tek faktörlü yapısına uyum sağladığı ve faktör yüklerinin .72 ile .79 arasında olduğu tespit edilmiştir. Ölçeğin uyum iyiliği değerleri diğer ölçeklerinki ile birlikte Tablo 1 'de sunulmuştur. Yapılan güvenirlik analizi sonucunda ölçeğin toplam Cronbach alfa güvenirlik katsayıs1 .82 olarak bulunmuştur.

\section{BULGULAR}

Araştırma sonucunda elde edilen verilere SPSS ve Amos programında analizler yapılmıştır. $\mathrm{Bu}$ kapsamda, ilk aşamada araştırmada kullanılan ölçeklerin doğrulayıcı faktör analizleri (CFA) yapılmıştır. CFA sonuçları Tablo 1' de toplu halde sunulmuştur.

İkinci aşamada ise katılımcıların algıladıkları psikolojik sermayenin öz-yeterlilik, iyimserlik, umut ve dayanıklılık boyutları ile örgütsel destek ve işe yabancılaşmalarına ilişkin elde edilen verilerin ortalamaları, standart sapmaları ve aralarındaki korelasyonlara bakılmıştır. Bulgular Tablo 2'de sunulmuştur. Analizin üçüncü aşamasında Baron ve Kenny (1986) tarafindan önerilen üç aşamalı hiyerarşik regresyon analizi ile aracılık etkisi araştırılmıştır.

Tablo 2'de de görüldüğü gibi araştırmaya konu edilen tüm bağımlı ve bağımsız değișkenler arasında anlamlı ilișkiler bulunmaktadır. Bu nedenle değişkenler arasında önemli etkiler öngörülebilmektedir. Analiz kapsamında modelde çoklu doğrusal bağlantı sorunu olup olmadığını belirlemek maksadıyla doğrudaşlığa (collinearity) da bakılmıştır. Elde edilen tolerans ve VIF değerleri bağımsız değişkenler arası çoklu bağlantı olmadığını doğrulayan sonuçlar vermiştir (Tolerans $>.2, \mathrm{VIF}<$ $10)$. 
Tablo 3. Arac1lik Testi Sonuçları (ÖZY-öD-IYB)

\begin{tabular}{|c|c|c|c|}
\hline & & $\begin{array}{l}\boldsymbol{\beta} \\
\text { ÖD }\end{array}$ & İYB \\
\hline & $\begin{array}{l}\text { Test l } \\
\text { Yaş } \\
\text { Çal. Süresi } \\
\text { ÖZY }\end{array}$ & & 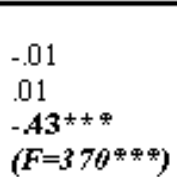 \\
\hline öZY & $\begin{array}{l}\text { Test } 2 \\
\text { Yaş } \\
\text { Cual. Süresi } \\
\text { ÖZY }\end{array}$ & $\begin{array}{l}-.03 \\
.02 \\
.61 * *+ \\
(F=396 \text { \%* })\end{array}$ & $\begin{array}{l}\text { ÖD } \rightarrow \text { IYB } \\
.001 \\
-.02 \\
-.74^{+*} \\
\left(F=514^{* *}\right)\end{array}$ \\
\hline & $\begin{array}{l}\text { Test 3 } \\
\text { Yaş } \\
\text { Ça1. Süresi } \\
\text { öZY } \\
\text { öD }\end{array}$ & & $\begin{array}{l}-.005 \\
-.01 \\
-.21^{*+*} \\
\mathbf{5 2} \\
(F=309 * * 4)\end{array}$ \\
\hline & Sobel Test(z) & $6.3^{4 \% 4}$ & \\
\hline
\end{tabular}

Analizin ikinci aşamasında ise psikolojik sermayenin öz-yeterlilik (ÖZY), iyimserlik (IYM), umut (UMT) ve dayanıklılık (DYN) boyutlarının işe yabancılaşma (IYB) üzerine etkisini ve bu etkide örgütsel desteğin (ÖD) aracılık rolünü açıklamak amacıyla, Baron ve Kenny (1986) tarafından önerilen üç aşamalı regresyon analizi yapılmıştır. $\mathrm{Bu}$ yönteme göre, bağımsız değişkenin bağımlı değişken ve aracı değişken üzerinde bir etkisi olmalıdır. Aracı değişken bağımsız değişkenle birlikte regresyon analizine dâhil edildiğinde, bağımsız değişkenin bağımlı değişken üzerindeki regresyon katsayısı düşerken, aracı değişkenin de bağımlı değişken (IYY) üzerinde anlamlı etkisi sürmelidir. Bu kapsamda ÖD düzeyinin aracılık rolünü belirlemek amaciyla, ÖZY-ÖD, IYYB; IYM-ÖD, IYYB; UMT-ÖD, IYYB ve DYN-ÖD, IYYB arasındaki ilişkiler hiyerarşik regresyon analizleri aracılığı ile incelenmiş ve Sobel testleri yapılmıştır. Aracılık testine iliş̧kin bulgular Tablo 3, 4, 5 ve 6'da verilmektedir.

Aracılık testi kapsamında ilk aşamada bağımsız değişken özyeterlilik ile işe yabancılaşma arasındaki ilişkilere bakılmıştır. $\mathrm{Bu}$ aşamanın ilk adımında ÖZY' nin IYYB' yi $(\beta=-.43, p<.001)$ anlamlı ve negatif olarak etkilediği görülmüştür. İkinci adımda ÖZY' nin aracıllğı araştırılan ÖD' ye olan etkisi incelenmiş̧tir. Analiz sonucunda ÖZY' nin ÖD' yi anlamlı olarak etkilediği $(\beta=.61, p<.001)$ tespit edilmiştir. Bu adımda aracılı̆ğ araştırılan ÖD' nin IYB' ye olan etkilerine de bakılarak rapor edilmiştir. ÖD' nin IYY' yi $(\beta=-.74, p<.001)$ anlamlı ve negatif olarak etkilediği bulgulanmıştır. $\mathrm{Bu}$ aşamanın son adımında ise ÖZY ve aracılığı araştırılan ÖD birlikte analize sokulmuş ve IYYB üzerindeki etkilerine bakılmıştır. Bu analiz sonucunda ÖZY' nin ÖD ile birlikte analize sokulmasıyla İYB üzerindeki etkisi devam etmiş ve azalmış $(\beta=-.21$, $\mathrm{p}<.001$ ), ÖD' nin de İYB üzerindeki etkisi devam etmiştir $(\beta=.52, p<.001)$. Bu şartların sağlanmasının ardından aracılık etkisini teyit etmek maksadiyla Sobel testi yapılmış ve Sobel(z) anlamlı bulunmuştur $(\mathrm{z}=6.3, \mathrm{p}<.001) . \mathrm{Bu}$ bulgu ÖZY'nin IYYB'ye etkisinde Ồ' nin kısmi aracılık rolü üstlendiğini göstermektedir. Bu bölüm analizleri sonucunda H1, H5, H9 ve aracilık hipotezi olan H10'un desteklendiği görülmektedir.

Aracılık testinin ikinci aşamasında ikinci bağımsız değişken iyimserlik ile işe yabancılaşma arasındaki ilişkilere bakılmıştır. $\mathrm{Bu}$ aşamanın ilk adımında IYM' in IYB' yi $(\beta=-.55, p<.001)$ anlamlı ve negatif olarak etkilediği görülmüştür. İkinci adımda IYM' in aracılığı araştırılan ÖD' ye olan etkisi araştırılmıştır. Analiz sonucunda IYYM' in ÖD' yi anlamlı olarak etkilediği $(\beta=.78, p<.001)$ tespit edilmiştir. Bu aşamanın son adımında ise IYM ve aracılığı araştırılan ÖD birlikte analize sokulmuş ve IYB üzerindeki etkilerine bakılmıştır. $\mathrm{Bu}$ analiz sonucunda IYM' in ÖD ile birlikte analize sokulmasıyla IYB üzerindeki etkisi devam etmiş ve azalmış $(\beta=-.36, p<.001)$, ÖD' nin de IYB üzerindeki etkisi devam etmiştir $(\beta=.48, \mathrm{p}<.001)$. $\mathrm{Bu}$ şartların sağlanmasının ardından aracılık etkisini teyid etmek maksadıyla Sobel testi yapılmış ve Sobel (z) anlamlı bulunmuştur ( $\mathrm{z}=6.5, \mathrm{p}<.001) . \mathrm{Bu}$ bulgu da İYM' in İYB'ye etkisinde ÖD' nin kısmi aracılık rolü üstlendiğini göstermektedir. Bu bölüm 
Tablo 4. Aracılik Testi Sonuçları (IYYM-ÖD-İYB)

\begin{tabular}{|c|c|c|c|}
\hline & & $\begin{array}{l}\boldsymbol{\beta} \\
\text { ÖD }\end{array}$ & IYYB \\
\hline & $\begin{array}{l}\text { Test l } \\
\text { Yaş } \\
\text { Ça1. Süresi } \\
\text { IYM }\end{array}$ & & $\begin{array}{l}-.02 \\
.01 \\
-55^{*+*} \\
\left(F=378^{* 4 . *)}\right.\end{array}$ \\
\hline İYM & $\begin{array}{l}\text { Test } 2 \\
\text { Yaş } \\
\text { Ca1. Süresi } \\
\text { IYM }\end{array}$ & $\begin{array}{l}-.04 \\
.02 \\
.78^{\star \star \star} \\
\left(F=387.2^{* \leftarrow 4}\right)\end{array}$ & \\
\hline & $\begin{array}{l}\text { Test 3 } \\
\text { Yaş } \\
\text { Ça1. Süresi } \\
\text { IYM } \\
\text { ÖD }\end{array}$ & & $\begin{array}{l}-.002 \\
.004 \\
-\mathbf{3 6} 6^{*+*} \\
\mathbf{A 8}^{*+*} \\
\left(F=315.6^{* * *}\right)\end{array}$ \\
\hline & Sobel Test $(z)$ & $6.5 \% 54$ & \\
\hline
\end{tabular}

analizleri sonucunda $\mathrm{H2}$, $\mathrm{H6}$ ve aracılık hipotezi olan H11' in desteklendiği görülmektedir.

Üçüncü adımda bağımsız değişken umut ile işe yabancılaşma arasındaki ilişkilere bakılmıştır. $\mathrm{Bu}$ aşamanın ilk adımında UMT' nin İYB' yi $(\beta=-.48$, $\mathrm{p}<.001)$ anlamlı ve negatif olarak etkilediği görülmüştür. İkinci adımda UMT' nin aracılığı araştırılan ÖD' ye olan etkisi incelenmiştir. Analiz sonucunda UMT' nin ÖD' yi anlamlı olarak etkilediği $(\beta=.76, p<.001)$ tespit edilmiştir. $\mathrm{Bu}$ aşamanın son adımında ise UMT ve aracılığ araştırılan ÖD birlikte analize sokulmuş ve İYB üzerindeki etkilerine bakılmıştır. Bu analiz sonucunda UMT' nin ÖD ile birlikte analize sokulmasıyla IYB üzerindeki etkisi devam etmiş ve azalmış ( $\beta=$ $.27, \mathrm{p}<.001)$, ÖD' nin de İYB üzerindeki etkisi devam etmiştir $(\beta=.52, \mathrm{p}<.001)$. Bu şartların

Tablo 5. Arac1lık Testi Sonuçlan (UMT-ÖD-IYY)

\begin{tabular}{|c|c|c|c|}
\hline & & $\begin{array}{l}\boldsymbol{\beta} \\
\text { ÖD }\end{array}$ & İYB \\
\hline & $\begin{array}{l}\text { Test l } \\
\text { Yaş } \\
\text { Ça1. Süresi } \\
\text { UMT }\end{array}$ & & $\begin{array}{l}-.02 \\
.01 \\
-.48^{*+*} \\
\left(F=344^{* * *}\right)\end{array}$ \\
\hline UMT & $\begin{array}{l}\text { Test } 2 \\
\text { Yaş } \\
\text { Ça1. Süresi } \\
\text { UMT }\end{array}$ & $\begin{array}{l}-.04 \\
.02 \\
76^{+*+} \\
\left(F=356.92^{* 4}\right)\end{array}$ & \\
\hline & $\begin{array}{l}\text { Test 3 } \\
\text { Yaş } \\
\text { Ça1. Süresi } \\
\text { UMT } \\
\text { ÖD }\end{array}$ & & $\begin{array}{l}-.002 \\
.004 \\
-.27^{*+*} \\
\mathbf{5 2}+*+ \\
\left(F=307.6^{* *}\right)\end{array}$ \\
\hline & Sobel Test(z) & $7.1 \%$ & \\
\hline
\end{tabular}


Tablo 6. Arac1lik Testi Sonuçları (DYN-ÖD-IYYB)

\begin{tabular}{|c|c|c|c|}
\hline & & $\begin{array}{l}\beta \\
\text { öD }\end{array}$ & IYYB \\
\hline & $\begin{array}{l}\text { Test l } \\
\text { Yaş } \\
\text { Ça1. Süresi } \\
\text { DYN }\end{array}$ & & $\begin{array}{l}-.02 \\
.01 \\
-58 *+* \\
\left(F=378.6^{* \% *}\right)\end{array}$ \\
\hline DYN & $\begin{array}{l}\text { Test } 2 \\
\text { Yaş } \\
\text { Ça1. Süresi } \\
\text { DYN }\end{array}$ & $\begin{array}{l}-.04 \\
.02 \\
.53^{+*+} \\
(F=362.3 * * 4)\end{array}$ & \\
\hline & $\begin{array}{l}\text { Test 3 } \\
\text { Yaş } \\
\text { Ça1. Süresi } \\
\text { DYN } \\
\text { ÖD }\end{array}$ & & $\begin{array}{l}-.002 \\
.004 \\
-.22^{*+*} \\
\boldsymbol{A} 1^{*+*} \\
\left(F=323.2^{* \star *}\right)\end{array}$ \\
\hline & Sobel Test $(z)$ & $6.2^{949}$ & \\
\hline
\end{tabular}

sağlanmasının ardından aracılık etkisini teyit etmek maksadıyla Sobel testi yapılmış ve Sobel(z) anlamlı bulunmuştur $(\mathrm{z}=7.1, \mathrm{p}<.001)$. Bu bulgu UMT'nin IYB' ye etkisinde ÖD' nin kısmi aracılık rolü üstlendiğini göstermektedir. Bu bölüm analizleri sonucunda H3, H7 ve aracılık hipotezi olan H12' nin desteklendiği görülmektedir.

Son olarak, bağımsız değişken dayanıklılık ile işe yabancılaşma arasındaki ilişkilere bakılmıştır. Bu aşamanın ilk adımında DYN' nin IYYB' yi $(\beta=-.58$, $\mathrm{p}<.001)$ anlamlı olarak etkilediği görülmüştür. İkinci adımda DYN' nin aracılığı araştırılan ÖD' ye olan etkisi incelenmiştir. Analiz sonucunda DYN' nin ÖD' yi anlamlı olarak etkilediği $(\beta=.53$, $\mathrm{p}<.001)$ tespit edilmiştir. $\mathrm{Bu}$ aşamanın son adımında ise DYN ve aracılığı araştırılan ÖD birlikte analize sokulmuş ve İYB üzerindeki etkilerine bakılmıştır. $\mathrm{Bu}$ analiz sonucunda DYN' nin ÖD ile birlikte analize sokulmasıyla IYYB üzerindeki etkisi devam etmiş ve azalmış ( $\beta=-.22, p<.001)$, ÖD’ nin de IYYB üzerindeki etkisi devam etmiştir $(\beta=.41, p<.001)$. $\mathrm{Bu}$ şartların sağlanmasının ardından aracılık etkisini teyit etmek maksadıyla Sobel testi yapılmış ve Sobel $(\mathrm{z})$ anlamlı bulunmuştur $(\mathrm{z}=6.2, \mathrm{p}<.001)$. Bu bulgu DYN' nin IYB' ye etkisinde ÖD' nin kısmi aracılık rolü üstlendiğini göstermektedir. Bu bölüm analizleri sonucunda $\mathrm{H4}, \mathrm{H8}$ ve aracılık hipotezi olan H13' ün desteklendiği görülmektedir. $\mathrm{Bu}$ sonuçla, regresyon analizleri ile test edilen toplam 13 hipotezin tamamı destek bulmuştur.

Modele ilişkin hipotez testi sonuçları toplu halde

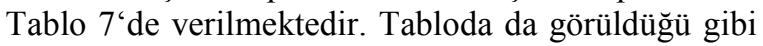

regresyon analizlerine göre tüm hipotezler destek bulmuştur. $\mathrm{Bu}$ kapsamda test edilen toplam 13 hipotezin tamamı destek bulmuştur.

\section{TARTIŞMA VE SONUÇ}

$\mathrm{Bu}$ çalışma ile psikolojik sermayenin dört boyutu olan öz yeterlilik, iyimserlik, umut ve dayanıklılığın çalışanların işe yabancılaşmasına etkisi ve bu etkide örgütsel desteğin aracılık rolü araştırılmıştır. Bu amaçla Ankara'da faaliyet gösteren savunma sanayi sektörü çalışanları üzerinde uygulamalı bir araştırma yapılmıştır. Bu araştırma ile analize dâhil edilen değişkenlerin işe yabancılaşma üzerindeki etkileri hiyerarşik regresyon analizi yardımıyla açıklanmaya çalışılmıştır. Yapılan araştırma ile savunma sanayi sektörüne ilişkin psikolojik sermaye - işe yabancılaşma ilişkisine yönelik açıklayıcı bulgular elde edilmiştir.

Analiz sonuçları incelendiğinde psikolojik sermayenin alt boyutlarının (öz-yeterlilik, iyimserlik, umut, dayanıklılık) tamamının örgütsel destek ve işe yabancılaşma ile ilişkili olduğu ve bu boyutların örgütsel desteği pozitif ve anlamlı olarak artırdığı, işe yabancılaşmayı ise negatif yönde anlamlı olarak etkilediği belirlenmiştir. $\mathrm{Bu}$ bulgulardan psikolojik sermaye ve örgütsel destekle ile ilgili olanlar, Özdevecioğlu (2003) ile Çetin ve arkadaşları (2013) tarafindan yapılan çalışmaları destekler niteliktedir. Psikolojik sermayenin işe yabancılaşmayı negatif ve anlamlı yönde etkilediği sonucu ise; Beğenirbaş'ın 
Tablo 7.Hipotez Testi Sonuçları

\begin{tabular}{|c|c|c|}
\hline Hipo tex & $\boldsymbol{\beta}$ & So nuç \\
\hline $\mathrm{OZY} \rightarrow \mathrm{IYB}$ & -0.43 & Desteklendi \\
\hline $\mathrm{I} Y M \rightarrow \mathrm{IYYB}$ & -0.55 & Desteklendi \\
\hline $\mathrm{UMT} \rightarrow \mathrm{IYYB}$ & -0.48 & Desteklendi \\
\hline $\mathrm{DYN} \rightarrow \mathrm{IYH}$ & -0.58 & Desteklendi \\
\hline$\ddot{O Z Y} \rightarrow \ddot{O D}$ & 0.61 & Desteklendi \\
\hline$\dot{I} Y M \rightarrow O ̈ D$ & 0.78 & Desteklendi \\
\hline $\mathrm{UMT} \rightarrow \mathrm{OD}$ & 0.76 & Desteklendi \\
\hline $\mathrm{DYN} \rightarrow \mathrm{OD}$ & 0.57 & Desteklendi \\
\hline$\ddot{O D} \rightarrow \dot{I Y B}$ & -0.74 & Desteklendi \\
\hline ÖZY'nin IYB'ye etkisinde ÖD'nin arac1lk etkisi vardir. & Kismi Aracilik & Desteklendi \\
\hline IYYM'nin IYYB'ye etkisinde ÖD'nin arac1lik etkisi vardır. & Kismi Arac1lik & Desteklendi \\
\hline UMT'nin IYB'ye etkisinde ÖD'nin arac1lik etkisi vardir. & Krsmi Aracilik & Desteklendi \\
\hline DYN'nin IYB'ye etkisinde ÖD'nin arac1lik etkisi vardir. & K1smi Arac1lik & Desteklendi \\
\hline
\end{tabular}

(2015) çalışmasını desteklemektedir. Buradan yola çıkılarak psikolojik sermayesi düşük olanların, işlerine karşı bir bağ hissetmemesi, yaptıkları işte kendilerini yeterli ve söz sahibi görmeyerek, işlerine yabancılaşmaları daha muhtemel bir sonuç olarak ortaya çıkmaktadır.

Örgütsel desteğin psikolojik sermaye ve işe yabancılaşma ile ilişkili olduğu ve psikolojik sermayeyi pozitif yönde anlamlı olarak arttırdığ1 sonucuna ulaşılmıştır. Bu bulgu benzer çalışmalarla (Bitmiş, 2015; Tüzün Kalemci vd, 2014) uyumludur.

Çalışan davranışlarına birçok değişkenin etkisinin olabildiği, psikolojik sermaye ve örgütsel desteğin de bazı değişkenler aracılığı ile çıktı değişkenlere yansıyabildiği düşünülmektedir. Bu düşünceden yola çıkarak psikolojik sermayenin işe yabancılaşmaya olan etkisinde örgütsel desteğin aracılık rolü araştırılmıştır. Elde edilen bulgulardan psikolojik sermayenin işe yabancilaşmaya etkisinde örgütsel desteğin kısmi aracılık rolü olduğu bulgusuna ulaşılmıştır. Bununla birlikte elde edilen diğer bulgulardan çalışanların algıladıkları psikolojik sermaye alt boyutlarından umut, iyimserlik, özyeterlilik ve dayanıklılık düzeyinin işe yabancılaşmayı etkisinde örgütsel desteğin kısmi aracılık rolü olduğu belirlenmiştir. Çalışanların iş performanslarının günümüz dünyasının zorlu rekabet koşullarının gerektirdiği zorlukların üzerinden gelebilecek düzeyde artması için çalışanın işe katılımına önem verilmesi, fikirlerinin önemsenmesi ve onların yaratıcılıklarının geliştirilmesine destek verilmesi konularına odaklanılması gerektiği düşünülmektedir.
$\mathrm{Bu}$ sonuçtan hareketle, örgütleri tarafindan desteklendiğini hisseden çalışanlar; daha iyimser atfetmeler yaparak olumsuz bir durumla karşılaştıklarında bu durumu dışsal, duruma özgü ve geçici olarak nitelendirecek ve amaçlarını gerçekleştirebilme adına üstlendikleri görevleri tamamlama konusunda kendilerine daha fazla güvenerek daha inançlı ve azimli vizyon geliştirebileceklerdir (Luthans vd., 2008 akt. Bitmiş, 2015: 239).

$\mathrm{Bu}$ kapsamda organizasyonlarda çalışanların psikolojik sermayeleri ve algıladıkları örgütsel desteğin işe yabancılaşma duygusunun azaltılmasında ya da ortadan kaldırılmasında önemli değişkenler olduğu ortaya konulmuştur. Son yıllarda gittikçe artan rekabet koşulları organizasyonlara daha yüksek düzeyde örgütüne bağlı, örgüte karşı güven duyan, örgütten destek bekleyen ve gördüğü destek ile birlikte performansı yükselen örgüte ve işine karş1 yabancılaşma hissetmeyen çalışanlar gerektirdiğini göstermektedir. Psikolojik sermayesi yüksek çalışanların örgüte artı değer kazandıracağı bunun yanı sıra örgütsel destek gibi aracı değerlerin de eklenmesi ile işe yabancılaşmanın ortadan kaldırılabileceğinin ortaya konulması bu çalışmanın önemli bir sonucudur. Böylelikle yöneticilere, psikolojik sermayenin çalışan tarafından algılanması aynı zamanda örgütsel destek gibi önemli bir örgütsel tutumun oluşturulması durumunda çalışanların işe yabancılaşma duygularının azalabileceği tavsiyesinde bulunulabilir.

$\mathrm{Bu}$ çalışmada elde edilen sonuçların, günümüzde önemi gittikçe artan örgütsel davranış çabalarının belirlenmesi ve bir organizasyonun en önemli unsuru 
olan insana dair bilinmezlerin keşfedilmesi adına önem arz ettiği düşünülmektedir. Organizasyonların her kademesinde bulunan yöneticiler tarafindan bu çalışma kapsamında değinilmiş olan kavramların etraflıca anlaşılması aralarındaki ilişkilerin çözümlenebilmesi ile birlikte önemli yönetsel ayrıcalıklar yaratılabileceği değerlendirilmektedir. Örgüt yönetiminin sahip olduğu insan kaynağına durağan bir kaynak olarak değil de pek çok boyutuyla geliştirilebilir bireyler topluluğu olarak bakabilmesi önem arz eden bir husustur.

Araştırmanın sadece savunma sanayi sektöründe ve bir bölgede yapılmış olması araştırmanın önemli kısıtlarındandır. Dolayısıyla diğer sektörlerde ve bölgelerde yapılacak araştırmalarda farklı bulgulara ulaşılabilir. Araştırmanın önemli bir diğer kısıtı da boylamsal olmamasıdır. Periyodik zaman aralıkları ile elde edilecek bulguların daha genel ve açıklayıcı niteliğe haiz olacağı değerlendirilmektedir.

\section{KAYNAKÇA}

Adams, J.S. (1965). Inequity in social exchange. İçinde L. Berkovitz (Ed.), Advances in experimental social psychology (Cilt.2, ss. 267-299). New York: Academic Press.

Abbas, M. \& Raja, U. (2014). Impact of perceived organizational politics on supervisory-rated innovative performance and job stress: Evidence from Pakistan. Journal of Advanced Management Science, 2(2), 1-34.

Afrasiabi, H., Solokloo, B.J. \& Ghodrat1, H. (2013). A study of job satisfaction in relation to participation and alienation. Journal of Applied Sociology, 49(1), 45-48.

Akçay, V.H. (2011). Pozitif psikolojik sermaye kavramı ve işletmelerde sürdürülebilir rekabet üstünlüğünü sağlamadaki rolü. Gazi Üniversitesi Iktisadi ve İdari Bilimler Fakültesi Dergisi, 13(1), 73-98.

Akkoç, İ., Çalışkan, A. \& Turunç, Ö. (2012). Örgütlerde gelişim kültürü ve algılanan örgütsel desteğin iş tatmini ve iş performansına etkisi: Güvenin aracılık rolü. Yönetim ve Ekonomi, 19(1), 105-135.

Akman, Y. \& Korkut, F. (2003). Umut ölçeği üzerine bir çalışma. Hacettepe Üniversitesi Eğitim Fakültesi Dergisi, 9, 193-202.

Armstrong-Stassen, M. \& Ursel, N.D. (2009). Perceived organizational support, career satisfaction, and the retention of older workers. Journal of Occupational and Organizational Psychology, 82, 201-220.

Avey, J.B., Wernsing, T.S. \& Luthans. F. (2008). Can positive employees help positive organizational change? Impact of psychological capital and emotions on relevant attitudes and behaviors. The Journal of Applied Behavioral Science, 44(1), 48-70.

Avey, J.M., Luthans, F. \& Jensen, S.M. (2009). Psychological capital: A positive resource for combating employee stress and turnover. Human Resource Management, 48, 677-693.

Banai, M., Reisel, W.D. \& Probst, T.M. (2004). Managerial and personal control model: Predictions of work alienation and organizational commitment in Hungary. Journal of International Management, 10(3), 375-392.

Bandura, A. (2001). Social cognitive theory: An agentic perspective. Annual Review of Psychology, 52, 1-26.

Baron, R.M. \& Kenny, D.A. (1986). The moderatormediator variable distinction in social psychological research: Conceptual, strategic, and statistical considerations. Journal of personality and social psychology, 51(6), 1173-1182.

Başaran, İ.E. (2008). Örgütsel davranış: Insanın üretim gücü. Ankara: Ekinoks Yayıncılık.

Beğenirbaş, M. (2015). Psikolojik sermayenin çalışanların 
duygu gösterimleri ve ișe yabancılaşmalarına etkileri: Sağlık sektöründe bir araştırma. Süleyman Demirel Üniversitesi, İktisadi ve İdari Bilimler Fakültesi Dergisi, 20(3), 249-263.

Bester, J., Stander, M.W. \& Zyl, L.E.V. (2015). Leadership empowering behaviour, psychological empowerment, organizational citizenship behaviours and turnover intention in a manufacturing division. SA Journal of Industrial Psychology, 41(1), 1-14.

Bıkmaz, H.F. (2004). Sınıf öğretmenlerinin fen öğretiminde öz yeterlik inancı ölçeğinin geçerlik ve güvenirlik çalışması. Milli Ĕ̈itim Dergisi, 31(161), 172-180.

Bitmiş, M.G. (2015). Algılanan örgütsel desteğin pozitif psikolojik kapasiteler üzerindeki etkisi: Hemşireler üzerine bir uygulama. İşletme Araştırmaları Dergisi, 7(1), 236-247.

Brandt, T., Gomes, J.F.S. \& Boyanova, D. (2011). Personality and psychological capital as indicators of future job success?. LTA, 3(11), 263-289.

Büyükyılmaz, O. \& Çakmak, A.F. (2014). ilişkisel ve işlemsel psikolojik sözleşmede algılanan ihlalin işten ayrılma niyeti ve algılanan örgütsel destek üzerindeki etkisi. Ege Akademik Baklş Dergisi, 14(4), 583-596.

Ceylan, A. \& Sulu, S. (2010). Work alienation as a mediator of the relationship of procedural injustice to job stress. International Journal of Business and Management, 5(8), 65-74.

Çakır, Ö. (2001). Isşe bağlılık olgusu ve etkileyen faktörler. Ankara: Seçkin.

Çavuş, M.F. \& Gökçen, A. (2015). Psychological capital: Definition, components and effects, British Journal of Education, Society and Behavioural Science, 5(3), 244255 .

Çelik, M. \& Bilginer, F.G. (2015). Psikolojik sermayenin iş tatmini üzerine etkisinde lidere duyulan güvenin aracılık rolü: Turizm sektöründe bir araştırma. 14. Ulusal İşletmecilik Kongresi Bildiriler Kitabı, 7- 9 May1s 2015, Aksaray, 530-536.

Çelik, M., Turunç, Ö. \& Bilgin, N. (2015). Çalı̧̧anların örgütsel adalet algılarının psikolojik sermaye üzerine etkisi: Çalışanların iyilik halinin düzenleyici rolü. Dokuz Eylül Üniversitesi Sosyal Bilimler Enstitüsü Dergisi, 16(4), 559-585.

Çetin, F. \& Basım, H.N. (2011). Psikolojik dayanıklılığın iş tatmini ve örgütsel bağlılık tutumlarındaki rolü. $\dot{I}_{s ̧}, G u ̈ c ̧$, Endüstri İlişkileri ve İnsan Kaynakları Dergisi, 13(3), 79-94.

Çetin, F. \& Basım, H.N. (2012). Örgütsel psikolojik sermaye: Bir ölçek uyarlama çalışması. Amme İdare Dergisi, 45(1), 121-137.

Çetin, F., Şeşen, H. \& Basım, H.N. (2013). Örgütsel psikolojik sermayenin tükenmişlik sürecine etkileri: Kamu sektöründe bir araştırma. Anadolu Üniversitesi Sosyal Bilimler Dergisi, 13(3), 95-108.

Dipietro, R.B. \& Pizam, A. (2008). Employee alienation in the quick service restaurant industry. Journal of Hospitality \& Tourism Research, 32(1), 22-39.

Eisenberger, R., Huntington, R., Hutchison S. \& Sowa, D. (1986). Perceived organizational support. Journal of Applied Psychology, 7, 500-507.

Erdem, H., Gökmen, Y. \& Türen, U. (2015). Psikolojik sermayenin örgütsel özdeşleşme üzerine etkisinde algılanan örgütsel desteğin aracılık rolü. Işsletme Araştırmaları Dergisi, 7(2), 38-62.

Erdem, M. (2014). İş yaşamı kalitesinin işe yabancılaşmayı yordama düzeyi. Kuram ve Uygulamada Eğitim Bilimleri Dergisi, 14(2), 519-544.

Eren, E. (2014). Örgütsel davranış ve yönetim psikolojisi (14. Bask1). İstanbul: Beta.

Erjem, Y. (2005). Eğitimde yabancılaşma olgusu ve öğretmen: Lise öğretmenleri üzerinde sosyolojik bir araştırma. Gazi Üniversitesi Türk Ĕ̈itim Bilimleri Dergisi, 4(3), 1-22.

Giray, M.D. \& Şahin, D.N. (2012). Algılanan örgütsel, yönetici ve çalışma arkadaşları desteği ölçekleri: Geçerlik ve güvenirlik çalışması. Türk Psikoloji Yazılarl, 15(30), 1-9.

Gohel, K. (2012). Psychological capital as a determinant of employee satisfaction. International Referred Research Journal, 3(36), 34-37.

Gürsoy, F. (2014). Sağllk işletmeleri personelinin işe yabancılaşma düzeyi: Van ili örneği (Yayınlanmamış Yüksek Lisans Tezi). Atılım Üniversitesi Sosyal Bilimler Enstitüsü, Ankara.

Hansen, A., Buitendach, J.H. \& Kanengoni, H. (2015). Psychological capital, subjective well-being, burnout and job satisfaction amongst educators in the Umlazi region in South Africa. SA Journal of Human Resource Management, 13(1), 1-9.

Harms, P.D. \& Luthans, F. (2012). Measuring implicit psychological constructs in organizational behaviour: An example using psychological capital. Journal of Organizational Behaviour, (33), 589-594.

Hirschfeld, R.R. \& Hubert S.F. (2000). Work centrality and work alienation: Distinct aspects of a general commitment to work. Journal of Organizational Behavior, 21(7), 789-800.

Jensen, S.M. \& Luthans, F. (2006). Relationship between entrepreneurs' psychological capital and their authentic leadership. Journal of Managerial Issues, 18(2), 254273. 
Kanten, P. \& Ülker, P. (2014). Yönetim tarzının üretkenlik karşıtı iş davranışlarına etkisinde işe yabancılaşmanın aracılık rolü. Muğla Sitkı Koçman Üniversitesi Sosyal Bilimler Enstitüsü Dergisi, 32, 16-40.

Karacaoğlu, K. \& Arslan, F. (2013). Çalışanların algıladıkları örgütsel desteğin tükenmişlik düzeyleri üzerine etkisi: Kayseri imalat sanayi uygulaması. Dokuz Eylül Üniversitesi Sosyal Bilimler Enstitüsü Dergisi, 15(3), 457-476.

Karakurt, A. (2012). Öğretmenlerin iş yerinde yalnızlık düzeyinin örgütsel destek ve bazı değişkenler açısından incelenmesi (Yayınlanmamış Yüksek Lisans Tezi). Necmeddin Erbakan Üniversitesi Eğitim Bilimleri Enstitüsü, Konya.

Kaya, U. \& Serçeoğlu, N. (2013). Duygu iş̧̧ilerinde işe yabancılaşma: Hizmet sektöründe bir araştırma. Çalışma ve Toplum Dergisi, 1, 311-346.

Luthans, F., Avey, J.B., Avolio, B.J. \& Peterson, S.J. (2010). The development and resulting performance impact of positive psychological capital. Human Resource Development Quarterly, 21(1), 41-67.

Luthans, F., Avolio, B.J., Avey, J.B. \& Norman, S.M. (2007). Positive psychological capital: Measurement and relationship with performance and satisfaction. Personnel Psychology, 60(3), 541-572.

Luthans, F., Norman, S.M., Avolio, B.J. \& Avey, J.B. (2008). The mediating role of psychological capital in the supportive organizational climate employee performance relationship. Journal of Organizational Behavior, 29, 219-238.

Luthans, F., Youssef, C.M. \& Avolio, B.J. (2006). Psychological capital: Developing the human competitive edge. USA: Oxford University Press.

Luthans, F., Youssef, C.M. \& Avolio, B.J. (2007). Psychological capital. New York: Oxford University Press.

Nabavi, S.A. \& Shahryari, M. (2014). Reasons and outcomes of work-family conflict and work alienation as one of its outcomes. Security and Social Order Strategic Studies Journal, 7(1), 13-15.

Nelson, D. \& Cooper, C.L. (2007). Positive organizational behavior. London: Sage Publication.

Norman, S.M., Avey, J., Nimnicht, J.L. \& Pigeon, N. (2010). The interactive effects of psychological capital and organizational identity on employee organizational citizenship and deviance behaviors. Journal of Leadership and Organizational Studies, 17(4), 380-391.

Özbek, M F. (2011). Örgüt içerisindeki güven ve işe yabancılaşma ilişkisinde örgüte uyum sağlamanın aracı rolü. Süleyman Demirel Üniversitesi İktisadi ve İdari Bilimler Fakültesi Dergisi, 16(1), 231-248.
Özdevecioğlu, M. (2003). Algılanan örgütsel destek ile örgütsel bağlılık arasındaki ilişkilerin belirlenmesine yönelik bir araştırma. D.E.Ü.İ.I.B.F. Dergisi, 18(2), 113-130.

Özdoğan, B. (2014). İşe yabancılaşma, örgütsel iklim ve koçluğun iş tatminine etkileri üzerine istanbul ilinde ampirik bir çalı̧̧ma (Yayınlanmamış Yüksek Lisans Tezi). Beykent Üniversitesi SBE, İstanbul.

Parasuraman, S., Greenhaus, J.H., \& Granrose, C.S. (1992). Role stressors, social support, and well-being among two career couples. Journal of Organizational Behavior, 13, 339-356.

Peterson, S. \& Luthans, F. (2003). The positive impact and development of hopeful leaders. Leadership and Organization Development Journal, 24(1), 26-31.

Polat, M. \& Yavaş, T. (2012). Yabancılaşma, kurumsal değerler ve duygu yönetimi denklemi. Eğitim ve Öğretim Araştırmaları Dergisi, 1(2), 218-224.

Polatç1, S. (2014). Psikolojik sermayenin görev ve bağlamsal performans üzerindeki etkileri: Polis teşkilatında bir araştırma. Ege Akademik Bakış Dergisi, 14(1), 115-124.

Ring, J.K. (2011). The effect of perceived organizational support and safety climate on voluntary turnover in the transportation industry. International Journal of Business Research and Management, 1(3), 156-168.

Rodoplu Şahin, D., Çubuk, D. \& Uslu, T. (2014). The effect of organizational support, transformational leadership, personnel empowerment, work engagement, performance and demographical variables on the factors of psychological capital. Emerging Markets Journal, 3(3), 1-17.

Sayü, P. (2014). The relationship between organizational justice and work alienation (Yayınlanmamış Yüksek Lisans Tezi). Marmara Üniversitesi SBE, İstanbul.

Sekaran, U. (1992). Research Methods For Business. Canada: John Wiley ve Sons, Inc.

Snyder, C.R. (2000). Handbook of hope: Theory, measures and applications. San Diego, CA: Academic Press.

Süral Özer, P., Topaloğlu, T. \& Timurcanday Özmen, Ö.N. (2013). Destekleyici örgüt ikliminin, psikolojik sermaye ile iş doyumu ilişkisinde düzenleyici etkisi. Ege Akademik Bakış Dergisi, 13(4), 437-447.

Şimşek, M.Ş., Çelik, A., Akgemci, T. \& Fettahlıŏlu, T. (2006). Örgütlerde yabancılaşmanın yönetimi araştırması. Selçuk Üniversitesi Sosyal Bilimler Enstitüsü Dergisi, 15, 569-587.

Taştan, S., İşçi, E. \& Arslan, B. (2014). Örgütsel destek algısının işe yabancılaşma ve örgütsel bağlılığa etkisinin incelenmesi: İstanbul özel hastanelerinde bir çalışma. Pamukkale Üniversitesi Sosyal Bilimler 
Enstitüsü Dergisi, 19, 121-138.

Tekingündüz, S., Kurtuldu, A. \& Eğilmez, Ç. (2016). Sosyal destek, işe yabancılaşma ve iş stresinin iş gören performans1 üzerindeki etkisinin incelenmesi. International Journal of Human Sciences, 13(1), 683694.

Tokmak, İ. (2014). Duygusal emek ile işe yabancılaşma ilişkisinde psikolojik sermayenin düzenleyici etkisi. İsletme Araştırmaları Dergisi, 6(3), 134-156.

Topçu, M.K. \& Ocak, M. (2012). Psikolojik sermayenin tükenmişlik algısı üzerine etkisinde iş tatmininin aracılık rolü: Türkiye ve Bosna-Hersek sağlık çalışanları örneği. 20.Ulusal Yönetim ve Organizasyon Kongresi Bildiriler Kitabı, 24-26 Mayıs, İzmir, 685690.

Tuna, M. \& Yeşiltaş, M. (2014). Etik iklim, işe yabancılaşma ve örgütsel özdeşleşmenin işten ayrılma niyeti üzerindeki etkisi: Otel işletmelerinde bir araştırma. Anatolia: Turizm Araştırmaları Dergisi, 25(1), 105-117.

Turner, N., Barling, J. \& Zaharatos, A. (2002). Positive psychology at work. In, C.R. Snyder \& S.J. Lopez (Ed.), Handbook of positive psychology (715-728). Oxford, UK: Oxford University Press.

Turunç, Ö. \& Çelik, M. (2010). Algılanan örgütsel desteğin çalışanların iş-aile, aile-iş çatışması, örgütsel özdeşleşme ve işten ayrılma niyetine etkisi: Savunma sektöründe bir araştırma. Atatürk Üniversitesi Sosyal Bilimler Enstitüsü Dergisi, 14(1), 209-232.

Tüzün Kalemci, İ., Çetin, F. \& Basım, H.N. (2014). The role of psychological capital and supportive organizational practices in the turnover process. METU Studies in Development, 41, 85-103.

Ünsar, A.S. \& Karahan, D. (2011). Yabancılaşmanın işten ayrılma eğilimini belirlemeye yönelik bir alan araştırması. Selçuk Üniversitesi İktisadi ve İdari Bilimler Fakültesi Sosyal ve Ekonomik Araştırmalar Dergisi, 15(21), 361-378.

Yalçın, İ. \& Koyuncu, S.C. (2014). Örgütsel yabancılaşma olgusunun iş tatmini üzerine etkisi: Niğde ilinde bir araştırma. KMÜ Sosyal ve Ekonomik Araştırmalar Dergisi, 16(26), 86-94.

Yıldırım Bozkurt, H. (2014). Örgütsel güven ile psikolojik sermaye arasındaki ilişkiyi belirlemeye yönelik bir araştırma (Yayınlanmamış Yüksek Lisans Tezi). Dumlupınar Üniversitesi SBE, Kütahya.

Yorulmaz, Y.I.., Altınkurt, Y. \& Y1lmaz, K. (2015). The relationship between teachers' occupational professionalism and organizational alienation. Educational Process: International Journal, 4(1-2), 3144. 